УдК 342.95

\author{
Л. B. Спицька
}

\title{
ПРАВОВЕ РЕГУЛЮВАННЯ АДМІНІСТРАТИВНОЇ ВІДПОВІДАЛЬНОСТІ ПОСАДОВИХ ОСІБ ОРГАНІВ ПУБЛІЧНОЇ АДМІНІСТРАЦІЇ ЗА ПОРУШЕННЯ У СФЕРІ НАДАННЯ АДМІНІСТРАТИВНИХ ПОСЛУГ
}

Розвиток правового регулювання інституту адміністративної відповідальності в Україні свідчить про необхідність захисту адміністративними санкціями все нових і нових відносин, що виникають у суспільстві. Одними з них $€$ відносини, що виникають у зв'язку із наданням адміністративних послуг.

Питання адміністративної відповідальності посадових осіб органів публічної адміністрації стали предметом дослідження таких науковців, як: В. Авер'янов, К. Афанасьєв, О. Бандурка, В. Бевзенко, І. Голосніченко, С. Ківалов, І. Коліушко, Т. Коломоєць, О. Кузьменко, Р. Мельник, С. Мосьондз, Н. Нижник, В. Олефір, С. Пєтков, Є. Соболь, М. Тищенко, В. Шкарупа та інші.

Згідно із Законом України «Про адміністративні послуги», посадові особи, уповноважені відповідно до закону надавати адміністративні послуги, та адміністратори несуть дисциплінарну, цивільну, адміністративну або кримінальну відповідальність, передбачену законом, за порушення вимог законодавства у сфері надання адміністративних послуг [1]. 3 огляду на викладене, суб'єктами відповідальності за порушення законодавства у сфері надання адміністративних послуг є посадові особи, уповноважені відповідно до закону надавати адміністративні послуги, до яких Закон відносить посадових осіб органу виконавчої влади, іншого державного органу, органу влади AРК, органу місцевого самоврядування, а також адміністратори. Предметом є - незаконні дії або бездіяльність посадових осіб, уповноважених відповідно до закону надавати адміністративні послуги, та адміністраторів. Закон передбачає такі види відповідальності: дисциплінарна, цивільна, адміністративна або кримінальна.

Метою статті $є$ аналіз питання адміністративної та дисциплінарної відповідальності посадових осіб органів публічної адміністрації за порушення у сфері публічно-сервісної діяльності.

Аналіз норм Закону України «Про адміністративні послуги» дозволяє констатувати, що порушення, які спричиняють настання відповідальності 
у сфері адміністративних послуг, стосуються саме порядку їх надання. До них належать: відмова у прийнятті заяви (ст. 9); вимагання від суб'єкта звернення документів або інформації для надання адміністративної послуги, не передбачених законом (ч. 6 ст. 9); порушення строків надання адміністративної послуги (ст. 10); порушення норм, що регулюють оплату за надання адміністративної послуги (ст. 11); прийом заяв, видача суб'єктам звернень оформлені результати надання адміністративних послуг (у тому числі рішень про відмову в наданні адміністративних послуг) суб'єктами надання адміністративних послуг, якщо такі послуги надаються через центри надання адміністративних послуг, крім випадків подання заяв через Єдиний державний портал адміністративних послуг (ст. 12); неналежне виконання або невиконання адміністратором основних завдань, відповідно до Закону, а саме: ненадання суб'єктам звернень вичерпної інформації та консультацій щодо вимог та порядку надання адміністративних послуг; неприйняття від суб'єктів звернень документів, необхідних для надання адміністративних послуг, їх реєстрація та подання документів (їх копій) відповідним суб'єктам надання адміністративних послуг не пізніше наступного робочого дня після їх отримання; невидача або незабезпечення направлення через засоби поштового зв'язку суб'єктам звернень результатів надання адміністративних послуг (у тому числі рішення про відмову в задоволенні заяви суб'єкта звернення), неповідомлення щодо можливості отримання адміністративних послуг, оформлених суб'єктами надання адміністративних послуг; незабезпечення організації надання адміністративних послуг суб'єктами надання адміністративних послуг; нездійснення контролю за додержанням суб'єктами надання адміністративних послуг термінів розгляду справ та прийняття рішень (ст. 13) [1].

Слід зауважити, що спроба внесення змін до Кодексу України про адміністративні правопорушення (КУПАП) була зроблена у проекті Закону України «Про внесення змін до деяких законодавчих актів України щодо спрощення умов ведення бізнесу (дерегуляція)» від 22.12.2014 № 1580. Відповідно до нього, до порушень вимог законодавства з питань надання адміністративних послуг, окрім зазначених вище, було віднесено: неповідомлення або несвоєчасне повідомлення суб'єктом надання адміністративної послуги суб'єкта звернення або адміністратора про відмову в наданні адміністративної послуги; порушення суб'єктом надання адміністративної послуги, підприємствами, установами або організаціями, що належать до сфери його управління, строків подання необхідних для надання адміністративної послуги документів або інформації; відмова суб'єкта надання адміністративної послуги суб'єкту звернення в наданні адміністративної послуги з підстав, не встановлених законом; стягнення із суб'єкта звернення не передбачених законом платежів за надання адміністративної послуги; неповідомлення або несвоєчасне повідомлення адміністратором суб'єкта звернення про можливість отримання адміністративної послуги, оформленої суб'єктом надання адміністративної послуги, або відмову в наданні такої послуги; безпідставна відмова адміністратора суб'єкту звер- 
нення у прийнятті заяви на отримання адміністративної послуги та документів, що додаються до неї. За ці порушення проект закону передбачав відповідальність у вигляді накладення штрафу на посадових осіб від тридцяти до п'ятдесяти неоподатковуваних мінімумів доходів громадян. А у разі повторного їх вчинення особою, яку протягом року було піддано адміністративному стягненню за такі ж порушення, - накладення штрафу на посадових осіб від п'ятдесяти до сімдесяти неоподатковуваних мінімумів доходів громадян (ст. 188-44) [2].

Проте наразі у Кодексі України про адміністративні правопорушення відсутні зазначені зміни, які б регулювали відповідальності за порушення встановленого Законом загального порядку надання адміністративних послуг.

3 огляду на викладене, можна припустити, що на сьогодні відсутня адміністративна відповідальність за порушення у сфері надання адміністративних послуг. Але ми з цим не погодимося. Адже, виходячи з переліку адміністративних послуг органів виконавчої влади, які надаються через центри надання адміністративних послуг [3], закони України, що регулюють окремі сфери, є частиною законодавства з надання адміністративних послуг. До них слід віднести закони України «Про Державний земельний кадастр» від 07.06 2011, «Про дозвільну систему у сфері господарської діяльності» від 06.09. 2005, «Про державну реєстрацію юридичних осіб, фізичних осіб-підприємців та громадських формувань» від 15.05.2003, «Про ліцензування видів господарської діяльності» від 02.03.2015, «Про державну реєстрацію речових прав на нерухоме майно та їх обтяжень» від 01.07.2004, «Про землеустрій» від 22.05.2003, «Про регулювання містобудівної діяльності» від 17.02.2011, «Про державну реєстрацію актів цивільного стану» від 01.06.2010, «Про житлово-комунальні послуги» від 09.11.2017, «Про соціальні послуги» від 19.06.2013, «Про державну допомогу сім'ям з дітьми» від 21.11.1992 тощо.

Водночас КУпАП містить відповідальність за окремі правопорушення [4]. Так, наприклад, ст. 166-10 «Порушення вимог законодавства 3 питань видачі документів дозвільного характеру» передбачає адміністративну відповідальність за неповідомлення або несвоєчасне повідомлення дозвільним органом суб'єкта господарювання або державного адміністратора про відмову у видачі документа дозвільного характеру; порушення дозвільним органом строків видачі документа дозвільного характеру; відмову дозвільного органу суб'єкту господарювання у видачі документа дозвільного характеру з підстав, не встановлених законом; анулювання документа дозвільного характеру дозвільним органом з підстав, не встановлених законом; неповідомлення або несвоєчасне повідомлення державним адміністратором суб'єкта господарювання про одержання документа дозвільного характеру або про письмову відмову у видачі документа дозвільного характеру; безпідставну відмову державного адміністратора суб'єкту господарювання у прийнятті заяви для одержання документа дозвільного характеру та документів, що додаються до неї; видачу (переоформлення, видача дублікатів, анулювання) державним адміністратором документа дозвільного 
характеру не в приміщенні дозвільного центру; видачу дозвільним органом документа дозвільного характеру, необхідність одержання якого не встановлена законом. За ці порушення передбачено накладення штрафу на посадових осіб від тридцяти до п'ятдесяти неоподатковуваних мінімумів доходів громадян. У разі вчинення особою, яку протягом року було піддано адміністративному стягненню за такого ж порушення - накладення штрафу на посадових осіб від п'ятдесяти до сімдесяти неоподатковуваних мінімумів доходів громадян.

Стаття 166-11 Порушення законодавства про державну реєстрацію юридичних та фізичних осіб передбачає відповідальність посадових осіб за порушення встановлених законом строків для проведення державної реєстрації юридичної особи, фізичної особи-підприємця або громадського формування, вимагання не передбачених законом документів для проведення державної реєстрації, а також інші порушення встановленого законом порядку проведення державної реєстрації юридичної особи, фізичної особи-підприємця або громадського формування у вигляді накладення штрафу на посадових осіб від двохсот до чотирьохсот неоподатковуваних мінімумів доходів громадян. Дії, передбачені частиною першою цієї статті, вчинені особою, яку протягом року було піддано адміністративному стягненню за такі самі порушення, тягнуть за собою накладення штрафу на посадових осіб від трьохсот до п'ятисот неоподатковуваних мінімумів доходів громадян. Окрім того, ця стаття визначає адміністративну відповідальність посадових осіб за порушення встановленого законодавством порядку пересилання реєстраційних справ юридичних осіб та фізичних осіб, порушення встановленого законом порядку зберігання реєстраційних справ юридичних осіб та фізичних осіб - підприємців.

Стаття 166-24 («Незаконні вимоги до документа») до документа, що подається суб'єктом господарювання до органу державної влади або органу місцевого самоврядування, передбачає адміністративну відповідальність за вимогу посадової особи органу державної влади або органу місцевого самоврядування про наявність на документі, що подається суб'єктом господарювання, відбитка його печатки або нотаріального засвідчення вірності копії документа, якщо обов'язковість такого нотаріального засвідчення не встановлена законом, або відмова у прийнятті документа у зв'язку з відсутністю на ньому відбитка печатки суб'єкта господарювання або нотаріального засвідчення вірності копії документа, якщо обов'язковість такого нотаріального засвідчення не встановлена законом у вигляді накладення штрафу від п'ятдесяти до ста неоподатковуваних мінімумів доходів громадян.

Стаття 166-12 Порушення законодавства у сфері ліцензування видів господарської діяльності регламентує відповідальність за неприйняття рішення, неоформлення, невидачу (ненадсилання) передбаченого законом документа органом ліцензування протягом встановленого законом строку; прийняття рішення, складання акта, видачу розпорядження органом ліцензування, що не відповідає нормам законодавства у сфері ліцензування; не внесення відомостей щодо ліцензування до Єдиного державного реєстру 
юридичних осіб та фізичних осіб - підприємців протягом передбаченого законодавством у сфері ліцензування строку; невиконання органом ліцензування у передбачений законом строк розпорядження про усунення порушень законодавства у сфері ліцензування.

Проте багато питань з надання адміністративних послуг залишаються неврегульованими законодавством, оскільки чинне профільне законодавство не відповідає вимогам норм Закону України «Про адміністративні послуги». Свого часу законодавець просто не врахував, який величезний масив змін до законодавства необхідний для реалізації положень ухваленого спеціального закону у сфері адміністративних послуг [5].

Отже необхідно внести зміни до КУпАП у частині передбачення відповідальності за порушення встановленого загального порядку надання адміністративних послуг, визначеного у Законі України «Про адміністративні послуги».

Якщо акцентувати увагу на інших видах відповідальності, то слід зауважити, що відповідно до ч. 2 ст. 41 Кодексу законів про працю, власник або уповноважений ним орган з власної ініціативи зобов'язаний розірвати трудовий договір з посадовою особою в разі повторного порушення нею вимог законодавства у сфері ліцензування, з питань видачі документів дозвільного характеру або у сфері надання адміністративних послуг, передбачених статтями 166-10, 166-12,188-44 Кодексу України про адміністративні правопорушення [6].

Окрім того, Закон визначає, що дії або бездіяльність посадових осіб, уповноважених відповідно до закону надавати адміністративні послуги адміністраторів - можуть бути оскаржені до суду в порядку, встановленому законом [1]. Треба зауважити, що тут не йдеться про можливість поза судового розгляду справи. Закон передбачає звернення до керівника ЦНАПу або до місцевого голови. Зазначаються незначні порушення, наприклад, порушення, пов'язані з якістю обслуговування, неналежне виконання посадових обов'язків, порушення внутрішнього трудового розпорядку, які тягнуть за собою не адміністративну, а дисциплінарну відповідальність. Окрім того, отримувач послуги може звернутися до вищого органу або посадової особи й у разі оскарження рішення органу публічної адміністрації $з$ надання адміністративних послуг. Йдеться про надання ЦНАПом місцевих послуг У разі скарги на зазначені порушення, вона розглядається відповідно до Закону України «Про звернення громадян», згідно з яким механізм розгляду полягає: 1) у праві громадянина особисто чи через представника протягом одного року з моменту його прийняття, але не пізніше одного місяця з часу ознайомлення з прийнятим рішенням, звернутися у порядку підлеглості до вищого органу або посадової особи; 2) в обов'язку вищого органу або посадової особи протягом одного місяця або невідкладно, але не е пізніше п'ятнадцяти днів від дня отримання скарги, об'єктивно та всебічно розглянути скаргу, скасувати або змінити оскаржувані рішення у випадках, передбачених законодавством України, якщо вони не відповідають закону або іншим нормативним актам, невідкладно вжити заходів до 
припинення неправомірних дій, виявити, усунути причини та умови, які призвели до порушень; забезпечити поновлення порушених прав, реальне виконання прийнятих у зв'язку із заявою чи скаргою рішень та письмово повідомити громадянина про результати перевірки заяви чи скарги і зміст прийнятого рішення. У разі визнання заяви чи скарги необгрунтованою, роз'яснити порядок оскарження прийнятого за нею рішення [7].

Щодо дисциплінарної відповідальності посадових осіб та адміністраторів, які згідно із законом надають адміністративні послуги, то на них поширюється дія законодавства про державну службу і службу в органах місцевого самоврядування. Так, відповідно до Закону України «Про державну службу», до них застосовується один із таких видів дисциплінарного стягнення: зауваження; догана; попередження про неповну службову відповідність; звільнення з посади державної служби [8].

Слід зауважити, що не зважаючи на відсутність норми у Законі України «Про адміністративні послуги» та Примірному регламенті ЦНАП, затвердженому Постановою КМУ від 01.08.2013 № 588, щодо оскарження дій працівників ЦНАПу до керівника ЦНАПу або до місцевого голови, локальні нормативно-правові акти окремих ЦНАПів передбачають таку можливість. Так, Регламент Центру надання адміністративних послуг Тетерівської сільської ради Житомирського району Житомирської області передбачає право особи подати скаргу на діiі чи бездіяльність персоналу ЦНАП, якщо вважає, що ними порушено ії права, свободи чи законні інтереси. Суб'єктом розгляду скарги на дії чи бездіяльність адміністраторів, працівників ЦНАП $€$ начальник ЦНАП або особа, яка його заміщає. Суб’єктом розгляду скарги на дії чи бездіяльність начальника ЦНАП є сільський голова у порядку, визначеному Законом України «Про звернення громадян». Керівник ЦНАП розглядає скаргу невідкладно, але не пізніше п'ятнадцяти днів з моменту iii реєстрації. У випадку, якщо скарга потребує додаткового дослідження матеріалів справи чи вчинення інших дій, необхідних для об'єктивного розгляду скарги, керівник ЦНАП має право подовжити термін розгляду скарги, але не більш ніж до тридцяти днів з моменту реєстрації скарги, про що повідомляє суб'єкта звернення письмово або в інший обраний суб'єктом звернення спосіб. Керівник ЦНАП вчиняє всі необхідні дії для прийняття об’єктивного рішення за скаргою та в межах своїх повноважень вирішує питання про дисциплінарну відповідальність працівників ЦНАП [9]. Подібні норми містяться в Регламентах ЦНАПів виконавчого комітету Ірпінської міської ради, Запорізької районної державної адміністрації, виконавчого комітету Івано-Франківської міської ради.

На підставі викладеного слід констатувати, що на сьогодні законодавство, що визначає адміністративну відповідальність посадових осіб органів публічної адміністрації за порушення у сфері надання адміністративних послуг є недосконалим і потребує відповідних змін і доповнень [10], оскільки неврегульованість цього питання спричиняє доволі вільне тлумачення норм чинного законодавства та у підсумку призводить до безвідповідальності посадових осіб як суб'єктів цих правовідносин. 


\section{Література}

1. Про адміністративні послуги: Закон України від від 06.09.2012 № 5203-VI. Відомості Верховної Ради. 2013. № 32. Ст. 409.

2. Про внесення змін до деяких законодавчих актів України щодо спрощення умов ведення бізнесу (дерегуляція): Проект Закону від 22.12.2014 №1580. URL: http:/ / w1.c1.rada.gov.ua/ pls / zweb2 / webproc4_1?pf3511=53076.

3. Деякі питання надання адміністративних послуг органів виконавчої влади через центри надання адміністративних послуг: Розпорядження КМУ від 16 травня 2014 р. № 523. URL: http: / / zakon3.rada.gov.ua/laws/show/523-2014-\%D1\%80.

4. Кодекс України про адміністративні правопорушення. Відомості Верховної Ради Української РСР. 1984. додаток до № 51. Ст. 1122.

5. Пліва О. Безвідповідальні адміністративні послуги: Матеріал аналітичного електронного видання «ЮРИСТ\&ЗАКОН». 2017 № 23. URL http://jurliga.ligazakon.ua/ news $/ 2017 / 7 / 5 / 161889 . h t m$.

6. Кодекс законів про працю України від 10.12.1971 № 322-VIII. Відомості Верховної Ради. 1971. додаток до № 50, Ст. 375 .

7. Про звернення громадян: Закон України від 02.10.1996 № 393/96-ВР. Відомості Верховної Ради України. 1996. № 47. Ст. 256.

8. Про державну службу: Закон України від 10.12.2015 № 889-VIII. Відомості Верховної Ради. 2016. № 4. Ст. 43.

9. Регламент Центру надання адміністративних послуг Тетерівської сільської ради Житомирського району Житомирської області, затверджений рішенням 3 сесії Тетерівської сільської ради 1 скликання від 18.01.2016. URL http://teterivska-gromada.gov.ua/ reglament-10-53-28-18-04-2016/.

10. Теорія адміністративного права: навч. посіб. СВ Пєтков. К.: КНТ, 2014. 187 с.

\section{Ано о а ці я}

Спицька Л.В. Правове регулювання адміністративної відповідальності посадових осіб органів публічної адміністрації за порушення у сфері надання адміністративних послуг. - Стаття.

У статті розглянуто законодавчі та підзаконні акти, що регулюють адміністративну відповідальність посадових осіб органів публічної адміністрації за порушення у сфері надання адміністративних послуг, висвітлено проблеми у нормативному регулюванні цього питання, здійснено аналіз механізму оскарження дій або бездіяльність посадових осіб, уповноважених відповідно до закону надавати адміністративні послуги, та адміністраторів

Ключові слова: адміністративна послуга, адміністративна відповідальність, дисциплінарна відповідальність, посадова особа, адміністратор, ЦНАП, оскарження.

\section{Анн н т а ци я}

Спицкая Л.В. Правовое регулирование административной ответственности должностных лиц органов публичной администрации за нарушения в сфере предоставления административных услуг. - Статья.

В статье рассмотрены законодательные и подзаконные акты, регулирующие административную ответственность должностных лиц органов публичной администрации за нарушения в сфере предоставления административных услуг, освещены проблемы нормативного регулирования этого вопроса, осуществлен анализ механизма обжалования действий или бездействия должностных лиц, уполномоченных в соответствии с законом оказывать административные услуги и администраторов.

Ключевые слова: административная услуга, административная ответственность, дисциплинарная ответственность, должностное лицо, администратор, ЦПАУ, обжалование. 


\section{S u m m a r y}

Spitska L.V. Legal Regulation of Administrative Responsibility of Public Administration Officials for Violations in the Sphere of Provision of Administrative Services. - Article.

The article deals with legislative and by-laws that regulate the administrative responsibility of officials of public administration authorities for violations in the provision of administrative services, highlight the problems of regulatory regulation of this issue, analyse the mechanism for appealing against acts or omissions of officials authorized by law to provide administrative services and administrators.

Key words: administrative service, administrative responsibility, disciplinary responsibility, official, administrator, CCPA, appeal. 